\title{
Marjaana Svala
}

\section{Elämä kertomuksena Torgny Lindgrenin romaaneissa Hummelhonung ja Pölsan}

Kiinnostus metaforaa ja etenkin kognitiivista metaforaa kohtaan on viriämässä uudelleen. Viime vuonna ilmestyi Monika Fludernikin toimittama artikkelikokoelma Beyond Cognitive Metaphor Theory. Tukholmassa vuosittain järjestettävä kansainvälinen metaforakonferenssi Metaphor Festival 2011 keräsi ennätysmäärän metafora-aiheisia esityksiä. Myös Avaimessa on käsitelty viime vuosina metaforaa: Anne Päivärinta on analysoinut kognitiivisen metaforan käyttöä runoanalyysissa (4/2010) ja Mikko Turunen semanttisen yhteisalueen käsitettä (1/2011). Bo Pettersson (2011a) puolestaan esitti edellisessä numerossa (4/2011), että metaforan tutkimuksen ja narratologian yhdistäminen on yksi keino tutkia mielikuvitusta kirjallisuudessa. Tämän artikkelin tarkoituksena on jatkaa kotimaista keskustelua kognitiivisesta metaforasta ja liittää se myös kertovien tekstien kontekstiin. Tarkastelen artikkelissani laajennetun kognitiivisen metaforan ELÄMÄ ON KERTOMUS käyttöä ruotsalaisen Torgny Lindgrenin (1938-) romaaneissa Hummelhonung (1995, HH) ja Pölsan (2002, P).

Moderni kognitiivisen metaforan tutkimus pohjautuu George Lakoffin ja Mark Johnsonin klassiseen teokseen Metaphors We Live By (1980), jossa tutkijat esittävät kaiken kielen pohjautuvan samanlaiseen substituutioon kuin metafora-trooppi. Lakoff ja Johnson pyrkivät häivyttämään klassista eroa arkisen ja poeettisen kielen välillä osoittamalla, että metafora on kognitiivinen väline, jota ihmiset luonnostaan käyttävät havainnoidessaan ja ymmärtäessään maailmaa. ${ }^{1}$ Myöhemmin ajatusta metaforasta kertomakirjallisuudessa on kehitellyt Paul Werth (1999, 317-329), jonka keskeisen väitteen mukaan kaunokirjalliset teokset voivat hyödyntää megametaforia (megametaphor, sustained metaphor) kertomuksen muodostuksessaan, sekä esimerkiksi Madeleine Kasten (2005), Peter Crisp (2008) ja Pettersson (2011b), jotka ovat olleet erityisen kiinnostuneita laajennettujen metaforien ja allegorian välisestä suhteesta.

Käytän artikkelissani Werthin (1999) ja Petterssonin (2011b) ajatusta laajennetusta metaforasta kertovan tekstin lähtökohtana. Erittelen sitä, millä tavoin Lindgrenin romaanit hyödyntävät laajennettua kognitiivista metaforaa ELÄMÄ ON KERTOMUS. Pyrkimyksenäni on osoittaa, miten laajennetun metaforan kautta romaaneissa käsitellään paralleeleja kahdenlaisen kertomisen, taiteellisen luomisen ja yksilön identiteetin rakentamisen, välillä. Identiteetin rakentamisella tarkoitan tässä prosessia, jossa omaa elämäntarinaa kerrotaan. Lisäksi esitän, miten elämän kuvaaminen kertomuk- 
sena on Pölsanissa yhteydessä myös toiseen laajennettuun kognitiiviseen metaforaan ELÄMÄ ON MATKA. Osoitan, että analysoimissani romaaneissa eksistentiaaliset ja metafiktiiviset kysymykset kietoutuvat toisiinsa kyseisten metaforien kautta. Näin pyrin jossain määrin haastamaan Magnus Nilssonin (2004) näkemyksen, että Lindgren on myöhäistuotannossaan kääntynyt teologisista ja eksistentiaalisista kysymyksistä kohti metafiktiivistä tematiikkaa. Vaikka metafiktiiviset kysymyksenasettelut, jotka tässä ymmärrän kysymyksiksi kirjoittamisen luonteesta ja ehdoista, ovatkin merkittävässä roolissa romaaneissa, ne ovat vuoropuhelussa eksistentiaalisen eli ihmiselämän merkitystä koskevan pohdiskelun kanssa. Näin myös Lindgrenin myöhäistuotanto jatkaa aiemman tuotannon eksistentiaalista linjaa, vaikka metafiktiiviset kysymykset nousevat siinä aiempaa voimakkaammin esille.

Lindgrenin, yhden Ruotsin tunnetuimman ja arvostetuimman kirjailijan, tuotantoa on tähän mennessä tutkittu vähän. Hummelhonungia on käsitelty muutamissa artikkeleissa (esim. Tyrberg 2002) sekä pienenä osana Nilssonin (2004) väitöskirjaa. Pölsania ei ole tutkittu lainkaan. Analysoimani romaanit ovat ensimmäinen ja toinen osa kolmen romaanin muodostamasta kokonaisuudesta, jota kirjailija on kuvannut trilogian sijaan triptyykiksi. Hän mieltää ne sekä erillisiksi taideteoksiksi että saman taideteoksen osiksi, jotka varioivat samaa tematiikkaa. (Nilsson, N.G. 2004.) Molemmat romaanit sijoittuvat Pohjois-Ruotsin kuvitteelliselle maaseudulle. Miljöön lisäksi niitä yhdistävät samankaltaiset teemat, motiivit ja tekstin rakenteet.

\section{Kun elämä ja kertomus sekoittuvat}

Hummelhonungin keskeisimmät henkilöt ovat kaksi kuolevaa vanhusta, veljekset Hadar ja Olof, joita liittävät toisiinsa vahvat vihan ja rakkauden siteet. Romaanin alussa kertoja saapuu veljesten asuinseudulle pitämään esitelmää, ja hänelle on järjestetty yöpymispaikka Hadarin luona. Hänen tarkoituksenaan on lähteä takaisin heti aamun valjetessa, mutta öinen lumisade saartaa asunnon. Kertoja jää veljesten luo kirjoittamaan kirjaa Pyhästä Kristoforoksesta. Samalla hän kuuntelee veljesten kertomuksia heidän elämästään. Olof esittää itsensä marttyyrina, joka on jäänyt isoveljensä varjoon. Hadar on ollut hänen läheisin lapsuudenystävänsä, mutta toisaalta vienyt hänen lelunsa - ja aikuisena myös hänen vaimonsa ja poikansa. Nyt hän on omistautunut pyrkimykselleen saada hyvitys kokemastaan, ja hän uskoo saavuttavansa sen parhaiten elämällä veljeään pitempään. Niinpä hän kuluttaa päivänsä mutustelemalla erilaisia makeisia, joiden uskoo vahvistavan häntä. Hadar puolestaan kuluttaa vain suolaisia elintarvikkeita ja kuvailee itseään vahvan isoisänsä heijastumana. Hänestä Olof on laiskuri, joka on saavuttanut kaiken elämässään ansaitsemattomasti ja aivan liian helposti. Jopa hänen makeanhimonsa kuvastaa hänen velttoa elämänasennettaan, jonka Hadar asettaa vastakohdaksi omalle suolaiselle tinkimättömyydelleen. Kun kertoja saapuu veljesten 
maailmaan, he ovat keskittyneet pyrkimykseensä karsia elämästään kaikki turha ja ylimääräinen. Olennaista on kysymys siitä, kumpi heistä voittaa elämän pitkittämisen taistelun. Kun lumiaura vihdoin avaa kertojalle tien, hänen elämänsä ja Kristoforoksesta kirjoittamansa kirja ovat niin kietoutuneet Hadarin ja Olofin elämään, että hän päättää jäädä seudulle kirjoittamaan teoksensa loppuun - ja auttamaan veljeksiä kuolemaan.

Lukija huomaa pian, että kertojan kirjoittaman kirjan ja hänen veljesten valkoisessa, lumen ympäröimässä maailmassa viettämänsä elämän välillä on yhtäläisyyksiä. Ensinnäkin kertoja huomauttaa suoraan, että hän kokee sukulaisuutta oman kirjoitusprosessinsa ja veljesten keskenään käymän kamppailun välillä:

Häruppe fann hon sig någotlunda väl tillrätta, hon kände, sade hon, en svårförklarlig förbundenhet med hans, Olofs, och broderns, Hadars, gemensamma förehavande, den ändamålslösa livsförlängningen tävlingslev, som hon inte kunde undgå att uppfatta som konstnärlig, föreställande năgot annat, och i någon mening likformig med hennes egna strävanden. (HH 72.)

Veljesten elämää kuvaava keskittyminen ja ylimääräisen karsiminen - sen pohtiminen, mikä on osa heidän elämäntarinaansa ja mikä ei - on kertojan mielestä tavallaan taiteellista ja sikäli yhtäläistä hänen omien pyrkimystensä kanssa. Pölsanin (P 60) kertoja mainitsee suoraan, että päätös siitä, mitä ottaa mukaan kertomukseen - mikä on olennaista ja välttämätöntä, mikä taas ylimääräistä - on keskeistä kirjoittajan työssä. Sekä kertomuksen kirjoittaja että ihminen, joka tarkastelee elämäänsä kertomalla siitä, kohtaavat samanlaisia kysymyksiä. Molemmat pohtivat, mitä asioita liittäisivät kertomukseensa ja millä tavoin esittäisivät ne.

Toiseksi, kun kertoja saapuu veljesten luo, hänet ympäröi yhtäkkiä satava puhdas luminen valkoisuus, joka halki romaanin vertautuu valkoiseen, kirjoittamattomaan sivuun: "Det hade börjat snöa igen, pappersliknande flagor som tycktes stå stilla i luften" (HH 64). Yllättäen satava valkoisuus johtaa kertojan ajatukset suoraan hänen omaan kirjoitustyöhönsä. Hän alkaa nähdä paralleeleja oman kirjoituksensa ja veljesten maailman välillä (HH 21). Valkoinen, ominaisuudeton maailma, jossa veljet elävät, vertautuu samaan, taustattomaan ja ominaisuudettomaan legendan maailmaan, josta kertoja itse kirjoittaa. Niitä yhdistää se, että ne heijastelevat valkoista sivua, jota kertoja alkaa täyttää henkilöillä ja toiminnalla. Veljesten elämäntarina on kertojan ja lukijan näkökulmasta vielä valkoinen, kirjoittamaton paperi, joka on vaipunut lumen peittoon unohduksiin (HH 125). Kertoessaan tarinansa veljekset ryhtyvät sanelemaan elämäntarinaansa tälle valkoiselle paperiarkille. Antaessaan veljesten kertoa elämästään kertoja paljastaa heidän tarinansa ja samalla täyttää tämän tyhjän paperin.

Kolmanneksi se kertomus, jota kertoja kirjoittaa, alkaa heijastaa ja varioida niitä tarinoita, joita veljekset kertovat kirjoittajalle, sekä niitä tapahtumia, joita hän todistaa heidän luonaan. Myös veljekset alkavat sekoittaa keskusteluissaan elämänsä ja kerto- 
muksen, jota hän kirjoittaa. Toisin sanoen he kaikki alkavat nähdä samankaltaisuutta kertojan kirjoittaman kertomuksen ja veljesten elämän välillä. Niinpä romaanin henkilöt muuttuvat hahmoiksi kertojan kirjoittamaan kirjaan ja heidän elämästään tulee hänen kirjoittamansa kertomus.

Kun Lindgren kiinnittää romaanissaan huomiota siihen, miten teksti ja elämä kietoutuvat toisiinsa, hän rakentaa romaania kognitiivisen metaforan ELÄMÄ ON KERTOMUS varaan. Elämän vertaaminen kertomukseen vaikuttaa mielettömältä, mutta elämän ja kertomuksen semanttisten yhtäläisyyksien kartoittaminen valottaa sitä, millä tavoin metafora toimii romaanissa. Turunen (2011) on esitellyt metaforaanalyysin tueksi semanttisen yhteisalueen käsitteen, jolla hän kuvaa metaforisen ilmauksen osien toisiaan leikkaavien semanttisten piirteiden joukkoa. Tuo piirrejoukko muodostaa merkityskentän, joka saa pintatasoltaan mielettömän (metaforisen) ilmauksen vaikuttamaan tulkinnassa mielekkäältä. Hummelhonungissa metaforaa käytetään osoittamaan paralleeleja taiteellisen luomisen, siis kirjan kirjoittamisen, ja kunkin ihmisen oman elämäntarinan kertomisen välillä. Romaanien Hummelhonung ja Pölsan välissä ilmestyneessä I Brokiga Blads vatten -novellikokoelmassa (1999) tämä yhtäläisyys kirjoitetaan myös eksplisiittisesti esille. Eräässä kokoelman novellissa (mts. 208) todetaan suoraan, että taiteellinen luomistyö on pohjimmiltaan samanlaista sisältöjen ja merkitysten etsimistä kuin ihmiselämä yleensäkin, mutta tiiviimmässä muodossa. Kysymys ei siis, tarkkaan ottaen, ole siitä, että elämä olisi kertomus. Pikemminkin elämäntarinan retrospektiivisessä kerronnassa ja taiteellisessa luomistyössä, kirjoittamisessa, nähdään semanttisia yhtäläisyyksiä, kuten rajallisuus, tiivistämisen vaatimus sekä pyrkimys sisältöjä ja juonta rakentamalla merkityksellistää maailmaa ja elämää.

Metaforassa ELÄMÄ ON KERTOMUS kirjoittaminen ja elämäntarinan kertominen yhdistyvät semanttisesti elämän jatkumisen kanssa, kun taas kuolema vertautuu sekä yksilön elämäntarinan päättymiseen että kirjoittajan tuskailuihin romaaninsa päättämisen kanssa. Hummelhonungin kirjoittaja-kertoja keskustelee Olofin kanssa tarinan ja henkilöiden elämäntarinoiden päättymisestä:

Hennes arbetsdagar blev längre och tyngre. Men ännu skrev hon, och till Olof sade hon: Snart är mitt skrivpapper slut, då är boken färdig, då ger jag mig av.

Men du ska ändå låta honom dö? sade Olof.

Vem?

Den där Kristofer som du skriver om.

Jag vet inte, sade hon. Hans död är inte särskilt viktigt.

En bok är väl inte färdig förrän människorna är döda? sade Olof.

Först kommer Hadar att dö, sade hon. Han kommer att dö innan jag är färdig med Kristofer. (HH 141.)

Keskustelu keriytyy ELÄMÄ ON KERTOMUS -metaforan ympärille. Olof osoittaa suoraan että kirja, jota verrataan elämään, ei ole valmis ennen kuin sen päähenkilö on 
kuollut. Hänen repliikkinsä jälkeen kertoja näyttää vaihtavan puheenaihetta siirtyessään käsittelemään Hadarin kuolemaa. Hän kuitenkin palaa samaan aiheeseen kuin Olof, koska hän huomauttaa, ettei hänen kirjoittamansa kirja ole valmis ennen Hadarin, sen keskeisen henkilön, kuolemaa. Kertojasta on tullut kirjoitustyössään Hadarin ja Olofin elämäntarinan kertoja, ja hänen kertomuksensa päättyy vasta kun Hadar on kuollut.

Ei ainoastaan kertojan kirjoittama teos vaan myös romaani Hummelhonung päättyy veljesten kuolemaan. ${ }^{2}$ Kuten mainitsin, halki romaanin valkeaa, koskematonta lunta verrataan kertomukseen, jota ei ole kirjoitettu tai joka on hiljennetty ja unohdettu - valkeaan sivuun. Romaanin lopussa lunta sataa jälleen (HH 159). Lumimyrskyn aikana veljekset kuolevat. Samaan aikaan kertoja kirjoittaa viimeiset virkkeensä (HH 162, 167). Romaanin kertoja saa Olofin ja Hadarin elämäntarinat päätökseen, mutta hänen oman tarinansa kerronta jää kesken. Niinpä romaanin viimeiset virkkeet kuvaavat hänen kirjoitustyötään. Hän voi siirtyä elämässään uuteen vaiheeseen päätettyään tarinan veljesten elämästä. Valkea lumi, kirjoittamaton paperi, edustaa tätä uutta elämänvaihetta ja uutta tarinaa, jota hän alkaa kirjoittaa palattuaan lumiauran kyydissä takaisin etelään. Triptyykin kolmannessa osassa, Dorés bibel-romaanissa (2005), kertoja saapuu samoille seuduille päättääkseen oman elämäntarinansa. Hän vertaa elämäntarinansa päättämistä kertomuksensa viimeisen pisteen kirjoittamiseen (mts. 94). Kun hän on, pyhimyksistä kertovan esitelmänsä kautta, päättänyt sen, myös hänen oma tarinansa peittyy unohduksen lumeen.

ELÄMÄ ON KERTOMUS -metafora jäsentää myös Pölsanin kehyskertomusta. Romaanin juoni etenee kahdella tasolla. Kehyskertomuksen vanhainkodissa elävä kertoja-kirjoittaja on odottanut puolet elämästään saadakseen kirjoittaa tarinansa, jonka kirjoittamisen hänen sanomalehtensä ankara päätoimittaja kielsi 53 vuotta sitten. Kun päätoimittaja kuolee, kertojalle avautuu mahdollisuus kertoa tarinaansa. Sisäkertomuksessa - hänen kirjoittamassaan tarinassa - kaksi muukalaista, Lars Högström ja Robert Maser, saapuvat tuberkuloosin riivaamaan Pohjois-Ruotsiin. He alkavat yhdessä kierrellä alueen kartoittamattomia seutuja päästäkseen maistamaan täydellistä pylssyä - ruokalajia, joka on alueen erikoisuus.

Samoin kuin Hummelhonungissa, myös Pölsanissa maailma, jota ei ole kirjoitettu, peittyy lumeen. Kun kertojaa kielletään kirjoittamasta, lumi peittää sen maailman, josta hänen ei sallita kertoa (P 7). ${ }^{3}$ Kertoja-kirjoittaja toteaa suoraan, että kirjoittamaton elämä on elämätöntä elämää:

Utan skrift rinner tiden bara förbi. Om någon hade frågat honom: Var har du gjort under alla dessa år, vad har hänt dig? hade han kommit att svara: Jag vet inte. Jag får väl se om eller när jag skriver det. (P 21.)

Kun hän ei ole saanut kirjoittaa ja tulkita elämää(nsä) kertomuksen muodossa, hän on ”jäänyt jälkeen” siitä mitä on tapahtunut. Niinpä hänen kokemusmaailmassaan vuodet 
eivät ole kirjoittamattomana aikana vierineet. Kun hänen sallitaan jälleen jatkaa kirjoitustyötään, hän kokee nuorenevansa: hän alkaa tutkiskella elämäänsä ja selvittää, mitä kaikkina hänen hiljaisuudessa viettäminään vuosina on tapahtunut.

\section{Elämäntarinaa juonellistamassa}

Lukuisat kirjailijat hyödyntävät ELÄMÄ ON KERTOMUS -metaforaa teoksissaan. Esimerkiksi Paul Austerin Moon Palacessa (1989) tulevaisuuden todetaan olevan kuin valkoinen paperi, ja kertoja pohtii, mitä hänelle tapahtuu kynän musteen loppuessa. Romaanissa vihjataan, että kuolema lähestyy tarinan tultua kerrotuksi. (Auster 1989, 41-42) Austerin romaanin kohtaus löytää paralleelin edellä kuvatusta Hummelhonungin lopusta, jossa veljesten kuolema yhdistetään heidän elämäntarinansa kirjoittamisen ja kertomisen päättymiseen. Hanna Meretoja (2010) esittää väitöskirjassaan, että etenkin ranskalaisessa kirjallisuudessa on 1970- ja 1980-luvuilta alkaen noussut esiin ajatus narratiivisesta subjektista. Ajatusta on kehitelty etenkin filosofisen hermeneutiikan tradition piirissä. Nähdäkseni kognitiivinen metafora, jonka mukaan ELÄM $\ddot{~}$ ON KERTOMUS, voidaan nähdä yhteydessä narratiiviseen subjektikäsitykseen, sillä kyseinen metafora tematisoi hermeneuttisen idean jokaisesta oman elämäntarinansa kertojana. Keskeisessä roolissa elämän kertomukseksi havaitsemisessa on Ricoeurin (1984, 31-51) juonellistamisen (emplotment) käsite. Juonellistamalla sidotaan yhteen näennäisesti yhteenkuulumattomia tapahtumia ja etsitään koherenssia, jonka yhteydessä kertomuksen tapahtuvat näyttäytyvät merkityksellisinä. Ricoeur (1991, 436-437) esittääkin, että narratiivinen identiteetti rakentuu tässä prosessissa, jossa menneitä kokemuksia muotoillaan kertomuksen muotoon.

Lindgrenin romaaneissa metaforan ELÄMÄ ON KERTOMUS avulla ei osoiteta ainoastaan yhtäläisyyksiä kirjoittajan ja tavallisen ihmisen elämäntarinan kertomisen - identiteetin luomisen - välillä, vaan samalla kiinnitetään huomiota myös juonellistamiseen elämää merkityksellistävänä tekijänä. Neumannin ja Nünningin (2008, 13-15) mukaan kertomuksen merkitystä identiteetin konstruoinnissa tematisoivat tekstit ovat usein juuri retrospektiivisiä kertomuksia, joissa kertoja tutkiskelee menneisyyttään ja pyrkii näkemään siinä mielekkyyttä ja yhtenäisyyttä kertomansa kertomuksen kautta. Narratiivista identiteettiä tematisoitaessa keskittyy huomio samalla siis myös subjektin pyrkimykseen reflektoida omaa elämäänsä ja nähdä se merkityksellisenä kokonaisuutena.

Sekä Hummelhonungissa että Pölsanissa elämälle etsitään merkitystä kertomalla ja juonellistamalla. Hummelhonungin yksi taso koostuu Hadarin ja Olofin, kuolemaa lähestyvien veljesten, itsetutkiskelusta. Veljekset paljastavat menneisyytensä vähitellen romaanin kertojalle ja esittävät samalla elämänsä kertomuksena, johon muodostuu kerrottaessa sen merkityksellistävä juoni. Tämä juoni keriytyy heidän yhteisen 
lapsuutensa, Olofin Minna-vaimon, heidän poikansa sekä Minnan ja pojan menetyksen ympärille. Veljesten kertomus kulminoituu tilanteeseen, johon kertoja saapuu: toisen veljen kuoleman odotukseen. Juonellistamisen kautta heidän on mahdollista nähdä koko elämänsä mielekkäänä kokonaisuutena: dramaattisena taisteluna ja selviytymiskamppailuna, joka päättyy toisen veljen kuoltua omaan ratkaisevaan voittoon.

Pölsanissa juonellistamisen kautta tapahtuva merkityksellistäminen tulee hyvin esille keskustelussa, jonka kehyskertomuksen kirjailija-kertoja käy hoitajansa Niklaksen kanssa. Kuvatessaan suhtautumistaan kirjoitustyöhönsä kertoja palaa keskustelussa lukuisia kertoja mening-sanaan:

Att du bara ids, sade Niklas när han satte ner frukostbrickan på bordet. Vad menar du?

Att stå där och skriva dagarna i ända, sade Niklas. Som om du hade timpenning. Som om du inte vore fri att göra vad du vill.

Jag gör bara en mening i taget. När jag hart gjort en mening skriver jag ner den. Har du någonsin tänkt på vad en mening egentligen är?

Vill du ha äppelmos till gröten? sade Niklas. Jag kan hämta äppelmos.

När man gör en mening, då är man fullkomligt fri. En mening som bara är sig själv. Att skapa meningar, det är det högsta och förnämsta i människolivet. Många lever åtti eller nitti år utan att åstadkomma en enda mening.

Gröten kallnar, sade Niklas. Den blir styv och omöjlig att äta. Och det blir skinn på mjölken.

Du blir äldre. Så småningom kommer du att begripa vad meningar betyder. Ibland kan det vara en ensam mening som skyddar oss från att bli utplånade. Vill du prova på att läsa det som jag har skrivit?

Ibland läser jag, sade Niklas. Men jag har strängt taget ingen glädje av det. Det fäster inte. Jag begriper allting men har ingen användning för det.

Nej, inte äppelmos. Jag tål inte syran. (P 56-57.)

Niklas pitää kirjoittamista tyhjänpäiväsenä ajanvietteenä, kun taas kertoja pyrkii todistamaan, että se merkityksellistää hänen elämänsä ja jopa pitää hänet hengissä. Ruotsin sana mening tarkoittaa sekä lausetta että merkitystä, ja Lindgren käyttää tätä monimerkityksisyyttä hyväkseen yhdistäessään kirjoittamisen metafiktiivisen ja eksistentiaalisen ulottuvuuden. Kertoja on vakuuttunut siitä, ettei elämän pituus ole sen merkityksellistämisen tae. Sen sijaan kyky nähdä elämä merkityksellisenä on sidoksissa pyrkimykseen esittää se lauseiden muodossa - olipa se sitten kirjailijan tarinankerrontaa tai ihmisen oman elämäntarinan kerrontaa. Elämän pukeminen sanoiksi on sen merkitykselliseksi tekemistä. Näin metafiktiivinen ja eksistentiaalinen ulottuvuus - kysymykset kirjoittamisesta ja elämän merkityksellisyydestä - kietoutuvat toisiinsa.

Juonellistamisen kautta avautuu myös yksi näkökulma narratiivisen subjektin ajallisuuteen. Ricoeur (1992, 147-149) kirjoittaa subjektin elämäntarinan juonellistamisesta, jolla hän viittaa subjektin pyrkimykseen jälkikäteen ymmärtää itseään ja maailmaa kertomuksen kautta. Juonellistamisen kautta menneisyys, nykyhetki ja tulevaisuus sekoittuvat toisiinsa. Samalla kun subjekti liikkuu muistissaan ajassa taaksepäin, hän 
pyrkii tekemään menneen osaksi nykyisyyttä. Toisaalta se tapa, jolla subjekti tulkitsee mennyttä, vaikuttaa siihen, millä tavoin hän suuntautuu tulevaisuuteen. (Ricoeur 1988, 215-216, 227, 234-235). Kun subjekti liikkuu muistissaan taaksepäin, hän esittää tapahtumat juonellisena kertomuksena, jotka liittävät menneen osaksi nykyhetkeä. Menneisyyteen palaaminen ja sen juonellistaminen on rekonstruointiprosessi, joka sitoo tapahtumat yhteen mutta jossa aina vallitsee myös epäjatkuvuuksia tai epäsointuisuuksia (discordance).

Pölsanin kertojan nuorentuminen samassa prosessissa, jossa hän kirjoittaa tekstiään, on metaforinen kuvaus tästä muistin liikkeestä taaksepäin. Kertoja kommentoi Lindahoitajalleen kirjoitustyötään, menneisyyden narratiivista tutkiskelua, seuraavasti:

Du kan tycka, sade han, att skrivandet är ett lättsamt tidsfördriv, du ser mig stå vid skrivpulpeten och du tänker att på detta vis får han ändå dagarna att gå, du inser inte att jag i själva verket anstränger mig till det yttersta, att jag samtidigt som mina krafter tillväxer förbrukar min kraft, dels rör jag mig i min egen kropp bakåt $\mathrm{i}$ tiden, dels tvingar tiden mig att skriva framåt, när dagen är slut förmår jag inte mer än aftonbönen och sömnen. (P 74-75.)

Kertomus, jota hän kirjoittaa, liikkuu eteenpäin samaan aikaan, kun hän liikkuu itse omassa kehossaan ajassa taaksepäin. Samassa prosessissa tutkimaton menneisyys, hänen omansa tai Martin Bormannin elämäntarina, tulee kirjoitetuksi. Lakoff, Johnson ja Turner ovat kognitiivista metaforaa käsittelevissä teksteissään kiinnittäneet huomiota siihen, että kognitiivisessa metaforassa tehdään usein konkreettisen seikan avulla ymmärrettäväksi abstraktia asiaa - esimerkiksi kirjoittamisen avulla voidaan metaforisoida elämää. Kuten Päivärintakin (2010, 9) huomauttaa, tällainen ajatus ei kuitenkaan sovellu ongelmitta kaunokirjallisiin teksteihin, ja haasteelliseksi se tulee myös mainitussa Pölsanin kohtauksessa, jossa kirjoittaminen esitetään kovin metaforisesti, ajallisena liikkeenä taaksepäin omassa kehossa. On myös kysyttävä, miten konkreettisena toimintana kirjoittaminen voidaan nähdä Hummelhonungissa, jossa Tyrbergin (2002) mukaan kirjoittamisen abstraktius ja aneeminen luonne asetetaan jatkuvasti kontrastiin elämän fyysisyyden ja kehollisuuden kanssa. Kumpi, elämä vai kirjoittaminen, on lopulta konkreettista ja kumpi abstraktia? Kumpaa tehdään ymmärrettäväksi toisen kautta? Pölsanin kertojan käyttämässä metaforassa on kuitenkin keskeistä sen vahvasti fyysinen ulottuvuus, joka myös tekee ilmauksen ymmärrettäväksi. Fauconnier ja Turner (2002, 377) esittävät, että juuri ruumiillisuuden ja fyysisyyden (embodiment) kautta tapahtuva tilallinen jäsentyminen auttaa metaforan hahmottumista. Pölsanin kertojan henkinen tila - muistelu - konkretisoituu hänen fyysisesti nuorentuvassa kehossaan. Sitaatissa kirjoittaminen ja laajemminkin elämän (kertomuksen kautta tapahtuva) merkityksellistäminen on toimintaa, joka tuodaan vuorovaikutukseen elämän kehollisuuden kanssa. Merkitysten etsiminen elämälle on, kerronnallistamisen tietynasteisesta abstraktiudesta huolimatta, tiiviisti sidoksissa elämän fyysisyyteen. 
Hummelhonungissa menneisyyden narratiivista tutkiskelua tapahtuu kahdella tasolla: veljekset muistelevat elämäänsä kertojalle, joka muistelee kokemuksiaan veljesten luona. Romaanin fragmentaarinen ja episodeista koostuva rakenne heijastelee tapaa, jolla kertoja kertaa omaa menneisyyttään. Kertojan kertomus ei ole yksinkertaisen lineaarinen ja jatkuva, vaikka se eteneekin noudattaen löyhästi kronologista järjestystä. Myös kertoja-kirjoittaja kiinnittää huomiota toistoihin kommentoidessaan omaa kirjoitusprosessiaan ( $\mathrm{HH}$ 64). Hän huomauttaa, että toisteinen ja fragmentaarinen kirjoitustapa saa tekstin lähenemään elämää, jota subjekti ei koe lineaarisena ja jatkuvana. Vaikka retrospektiivinen merkityksellistämisen pyrkimys yhdistää romaanissa sekä subjektin elämäntarinan kerrontaa että kirjoittamista, ei itse kertomuksen käsitteeseen välttämättä liity semanttisesti lineaarisuuden ja koherenttiuden vaatimusta. Kertojan huomautus kiinnittäkin huomiota siihen, millaisista piirteistä elämän ja kertomuksen välinen semanttinen yhteisalue romaanissa löytyy: epäjatkuvuudesta, toisteisuudesta ja fragmentaarisuudesta. Molempia - elämää ja kertomusta - luonnehtivat erilaiset heijastuma-, peili- ja toistorakenteet, ja tekstin toisteisuus heijastelee subjektin ajallisuuden kokemusta. Hummelhonungin veljeksetkään eivät kuvaa menneisyyttään yhtenäisenä tarinana, vaikka kertoja rekonstruoikin juonellisen tarinalinjan heidän kertomiensa tapahtumien pohjalta. Kertoessaan esimerkiksi äitinsä hautajaisista Hadar huomauttaa, että hänen muistikuvansa tapahtuneesta päättyy yhtäkkiä (HH 83). Niinpä myös hänen rekonstruoiva kertomuksensa pysähtyy. Teoksen moninkertaisesti fragmentaarinen rakenne välittääkin lukijalle subjektin kokemusta ajallisuudestaan. Tämän kirjallisuuden kyvyn luoda kuvitteellisia variaatioita ajallisuuden kokemuksesta Ricoeur (1985, 100-152; 1988, 127-141; 1992, 148) nostaa esiin yhtenä kirjallisuuden omimmista ja keskeisimmistä piirteistä.

\section{Elämä, kirjoittaminen, kertomuksenetsintämatka ja armo}

Pölsanissa ELÄMÄ ON KERTOMUS -metafora on myös yhteydessä metaforaan ELÄMÄ ON MATKA (jolla etsitään kertomusta). Pettersson (2011b) huomauttaa, että kertovat tekstit voivat aloittaa laajennetun metaforan kehittelyn jo otsikossaan. Myös Pölsanin nimi on tiiviissä yhteydessä romaania hallitseviin laajennettuihin metaforiin. Romaanin sisäkertomuksen päähenkilöt, Robert ja Lars, kehittävät kertomuksen etsimisestä intohimonsa kohteen. Suuri osa sisäkertomusta koostuu heidät halki kuvitteellisen Pohjois-Ruotsin johdattavasta matkasta, jonka pyrkimyksenä on löytää täydellinen pylssy (pölsan). Elämä, joka on aiemmin näyttäytynyt merkityksettömänä vaelteluna, paljastuu uudessa, merkityksellisessä valossa, kun he vihdoin löytävät sen:

Om livet har varit tomt och meningslöst och man möter pölsan, då säger man till sig själv: det finns trots allt en grund eller karma eller mittpunkt i det omätliga och gränslösa, man är inte tvungen att ge upp. (P 174.) 
Romaanissa todetaan, ettei pylssy ole ainoastaan ruokalaji, vaan sen nimi pohjautuu kreikan balsamon-sanaan ja merkitsee siten myös kuvaannollisesti esimerkiksi armoa ja lohdutusta (P 204). Matka, jossa Robert ja Lars etsivät pylssyään, on heidän elämänsä todellinen sisältö, ja matkustaessaan he etsivät pohjimmiltaan kertomusta, joka varustaisi heidän elämänsä merkityksellä. Pölsanissa tämä kertomus näyttäytyy myös ainoana armona, jonka ihminen löytää muuten merkityksettömältä vaikuttavassa elämässään. Larsille pylssy näyttää myös hänen elämänsä aiemmat tapahtumat merkityksellisinä. Hän on kärsinyt pitkään tuberkuloosista, mutta parantunut ja tullut taudille immuuniksi. Täydellinen pylssy puolestaan sisältää tuberkkeleita, ja ilman sairaushistoriaansa hän ei kykenisi maistamaan sitä. (P 187-188.)

Kuitenkin on huomattava, että yllä lainatussa kohtauksessa, jossa maistellaan täydellistä pylssyä, käytetään vapaata epäsuoraa esitystä. Siinä fokalisaatio kätkeytyy, eikä lukija ole varma, onko kyseessä Larsin tai Robertin sisäinen puhe - heidän näkökulmastaan välittyvä pylssyn ylistys - vai kertojan ironia, jonka kautta pylssystä löytyvä elämän merkitys näyttäytyy naurettavana. Jälkimmäistä tulkintaa tukee kohdassa tapahtuva tyylin muutos, jossa romaania vallitseva lakoninen tyyli muuttuu liioittelevaksi paatokseksi, joka on ironisessa kontrastissa sekä pylssyyn maanläheisenä ruokalajina että siihen liitettäviin yleviin merkityksiin. Toisaalta kertomuksessa löydettävä elämän merkitys on yhtäläinen myös kehyskertomuksen tason kertojan välittämän maailmankuvan kanssa. Niinpä romaanin lukija jää tilanteeseen, jossa pylssyn kuvaukseen liittyvää ambivalenttiutta on mahdotonta ratkaista, ja pylssyssä löydettävä elämän merkitys kaksoisvalottuu yhtä aikaa sekä naurettavaksi että armolliseksi.

Metaforat ELÄMÄ ON KERTOMUS ja ELÄMÄ ON MATKA yhdistyvät Pölsanissa myös siten, että kirjoittaminenkin esitetään matkana. Keskustellessaan Lindan kanssa kehyskertomuksen kirjoittaja osoittaa kirjoittajan ja tutkimusmatkailijan välisiä yhtymäkohtia seuraavasti: upptäcka.

När han tystnad sade Linda: Men man undrar ju vad det han försöker

Han forskar. Han är forskningsresande. I största allmänhet.

Fast själv vet hand nog, sade Linda, vad det är han letar efter.

Det är antagligen omöjligt att veta på förhand.

Ingen människa kan fara omkring på det sättet utan att verkligen försöka hitta något särskilt.

Han har väl hammare och hacka och knackar flisor ur isen. Man kan ju aldrig veta. (P 155.)

Lainauksessa leikitellään ilmauksen knacka flisor monimerkityksellisyydellä. Flisor, kuten suomen sana liuska, viittaa sekä jäästä irtoaviin liuskoihin että paperiliuskoihin. Metaforan luoma paralleeli on ilmeinen: kirjoittaja on tutkimusmatkailija, joka kirjoittaessaan kartoittaa tutkimattomia seutuja. Romaanissa verrataankin toisessa yhteydessä kirjoittajan ja naparetkeilijän tutkimuksia samalla tavoin: "Det sannfärdiga ljugan- 
det måste utföras helhjärtat och med en målmedvetenhet som kunde liknas vid en nordpolsfarares" (P 59). Kirjoittajan ja tutkimusmatkailijan tehtävät sekoittuvat konkreettisestikin romaanin sisäkertomuksessa, jossa Lars ja Robert ryhtyvät kirjoittamaan kirjaa pylssynetsintäretkestään. Lauseiden ja merkitysten - mening - luominen yhdistää kirjoittajan työn tavallisen ihmisen elämän merkityksen etsintään, jotka molemmat näytetään yhtä aikaa sekä armollisessa että hieman naurettavassa valossa.

ELÄMÄ ON KERTOMUS ja ELÄMÄ ON MATKA -metaforat liittyvät toisiinsa osin päällekkäisten semanttisten yhteisalueidensa kautta. Elämää, kertomusta ja matkaa luonnehtivat romaanissa esimerkiksi rajallinen kesto ja etsimisen kautta tapahtuva merkityksellistämisen pyrkimys. Päämärätietoisuus ja teleologisuus liittyvät sekä kertomukseen että matkaan. Toisaalta romaanissa esitetään, että ihmiselämästä määränpää puuttuu: "då kan man aldrig känna sig som något annat än som en vandrare, även om man inte är på väg mot något mål, för det finns inget mål” (P 104). Pölsanissa viritelläänkin jatkuvasti ajatusta sen hyödyntämien metaforien välisten semanttisten yhteisalueiden rajoista - etenkin siitä kysymyksestä, miten hyvin kertomusmetafora onnistuu kuvaamaan elämää.

\section{Vai onko elämä sittenkään kertomus?}

Elämän kerronnallistamista vastustavat piirteet ovat saaneet viimeaikaisessa tutkimuksessa melko paljon huomiota ${ }^{4}$, ja myös Pölsanissa ajatusta elämästä kertomuksena käytetään sekä romaanin yhtenä kantavana metaforana että kyseenalaistetaan sen metaforinen kuvausvoima. Kun Hummelhonung hyödyntää itsetietoisesti ja konventionaalisesti ELÄMÄ ON KERTOMUS -metaforaa tarinankehittelyssään ja esittää romaanin henkilöiden elämän kertomuksena, joka päättyy tarinan sivujen loputtua, leikittelee Pölsan ajatuksella tällaisesta yhdestä, rajallisesta elämäntarinasta. Romaanin kertoja nimittäin kohtaa tilanteen, jossa ne paperit, joihin hän kirjoittaa elämäntarinaansa, uhkaavat loppua. Romaanissa hyödynnettävän ELÄMÄ ON KERTOMUS -metaforan mukaan kertojan elämäntarinan tulisi päättyä siis päättyä. Kertoja ei kuitenkaan suostu päättämään tarinaansa ja kuolemaan. Sen sijaan hän uudelleen virinneessä elämänhalussaan päättää anoa lisää kyniä ja paperia kunnallisneuvokselta. Lopulta hän saa haluamansa - ja jatkaa sekä kirjoittamistaan että elämäänsä.

Lakoff ja Turner ovat metaforatutkimuksissaan kehitelleet invarianssiperiaatetta, jonka mukaan metaforaa hahmotettaessa lähtöaineksen skemaattinen olemus säilyy. Päivärinta $(2010,12)$ tulkitsee tämän tarkoittavan, että metaforisessa kartoittamisprosessissa "lähtöaineksen olemusta vastaan ei saa rikkoa". Hän kritisoi invarianssiperiaatetta esittämällä, että jos elämää kuvataan esimerkiksi matkana, "invarianssihypoteesin mukaan metafora ei voi rakentua sen konventionaalisesti tuotettua olemusta vastaan, vaikkapa siten, että - - matkalla ei olekaan ajatuksellisesti päätepistettä". Samanlaista kritiikkiä 
invarianssihypoteesia kohtaan voi esittää myös Pölsanin perusteella. Ajatus kuolemisesta paperinipun loppuessa osoittaa, millaisiin absurdiuksiin metaforan ELÄMÄ ON KERTOMUS ottaminen liian vakavasti voi johtaa. Romaanissa tullaan siis elämän ja kertomuksen välisen semanttisen yhteisalueen rajoille. Kertomus on yksi metafora, jonka kautta elämää voi käsitellä, mutta tavoittaa vain joitakin aspekteja elämästä. Joissain suhteissa elämä on myös eri asia kuin kertomus.

Ricoeur $(2000,113)$ korostaa, että koska metaforassa lähtöaines ja kuvattava aines eivät ole koskaan täysin yhteneviä, muodostuu metaforan merkitys yhtäläisyyden lisäksi myös ilmaisujen välisistä vallitsevien eroista. Pölsan tarttuu leikkisin ottein metaforan mahdollistamaan eron näkökulmaan. Kirjallisen teoksen kirjoittaminen ja oman elämäntarinan kertominen näyttäytyvät romaaneissa monissa suhteissa samanlaisena prosessina, joiden kertojat kohtaavat yhtäläisiä haasteita esimerkiksi koherenssin luomisen suhteen sekä näkevät elämän käsittelyn kertomuksen muodossa merkityksellistävän elämäänsä. Yhtäläisyyksiä löytyy kertojuuden suhteen: ihminen kertoo elämäntarinaansa samalla tavoin juonellistaen kuin kirjailijakin omaa tarinaansa. Ricoeur (1992, 148-151, 158-163) esittää, että ihminen tulkitsee omaansa ja muiden elämää kuin romaanin henkilöhahmon kertomusta. Pölsan kuitenkin kiinnittää huomiota siihen, että ihminen ei ole omassa elämäntarinassaan samassa roolissa kuin romaanin henkilöhahmo. Sen sijaan hänellä on kertojan vapaus halutessaan hypätä ulos yhdestä identiteettikertomuksestaan, vaieta siitä tai vaikkapa aloittaa kokonaan uusi tarina, kuten Pölsanin sisäkertomuksessa natsi-Saksan entinen sotarikollinen Martin Bormann, joka vaihtaa nimensä Robert Maseriksi, tekee muistinmenetyksen turvin. Ihmisillä on mahdollisuus muuttua ja aloittaa elämässään uusia kertomuksia. Subjektin ei ole tarpeen ylläpitää samaa narratiivista identiteettiä halki elämänsä, eikä aiempi kertomus välttämättä ohjaile kertomuksen jatkoa tai uuden kertomuksen suuntaa. Elämä ei siis, kuten Ricoeurkin $(1992,161)$ toteaa, ole vain yksi kertomus, vaan koostuu mahdollisuudesta esittää elämä kudelmana erilaisia, enemmän ja vähemmän toisiinsa kietoutuneita kertomuksia.

Jos Lindgrenin romaanit sitten käyttävät laajennettuja kognitiivisia metaforia tarinankehittelynsä lähtökohtana, ovatko ne allegorioita? Pettersson (2011b) esittää muun muassa Kasteniin (2005) tukeutuen ajatuksen, että laajennetut metaforat ovat läheistä sukua allegorialle. Kysymys allegoriasta on relevantti Lindgrenien romaanien kohdalla myös siksi, että kirjailija on haastatteluissa todennut velkansa allegorian periaatteelle ja todennut näkevänsä kokonaisen kertomuksen laajana metaforana ${ }^{5}$, kun taas toisaalta Nilsson (2004, 240-242) hylkää ajatuksen esimerkiksi Hummelhonungin allegorisuudesta sillä perusteella, ettei romaanin henkilöhahmoja voi samastaa tiettyyn abstraktiin käsitteeseen romaanin erilaisten peilirakenteiden vuoksi. Kysymykseen romaanien allegorisuudesta on mahdoton vastata ottamatta kantaa allegorian käsitteen määrittelyyn. Tämän artikkelin kannalta vastauksen antamista keskeisempää on 
huomion kiinnittäminen siihen, miten etenkin Pölsan heittää haasteen myös laajennettujen metaforien tutkimukselle. Miten teoria laajennetun metaforan ja allegorian suhteesta reagoi sellaisiin teoksiin, jotka sekä itsetietoisesti hyödyntävät laajennettua metaforaa tarinankehittelyssään että myös toistuvasti haastavat samaa metaforaa ja sen kuvausvoimaa?

\section{Viitteet}

${ }^{1}$ Pettersson (2008, ks. myös 2011b) huomauttaa, että tämä käsitys muodostaa vastakohdan nk. narratiivisessa käänteessä esiin nousseelle ajatukselle, jonka mukaan havaitsemme ja tulkitsemme maailmaa kertomuksen muodossa. Hänen mukaansa figuraalisen ja narratiivisen lähestymistavan edustajat eivät juuri ole antautuneet vuorovaikutukseen tai edes väittelyihin, vaan ovat pääosin jättäneet vastapuolen lähestymistavan huomiotta. Vähälle huomiolle on jäänyt se, että jo Ricoeur painotti metaforan ja kertomuksen välistä yhteyttä. Ricoeurin ajatuksista metaforan ja kertomuksen yhteydestä ks. esim. Ricoeur 2005, 165 ja Ricoeur 2000, 83.

${ }^{2}$ Tyrberg $(2002$, 355) ja Nilsson (2004, 245-246) huomioivat sen tulkintamahdollisuuden, että lukijan lukema teos on se kirja, jota kertoja kirjoittaa. He kiinnittävät erityisesti huomiota sivunumeroihin: sivulla 155 kertoja toteaa kirjoittaneensa noin 150 sivua ja sen keskivaiheilla toteaa olevansa noin puolivälissä työtään. Samalla tavoin voisi tulkita Pölsania, jossa eletty vuosi on yhteydessä kirjoitettuun sivuun. Kertojan hiljaisuus on kestänyt 53 vuotta. Niinpä hän ei ole elänyt 53 vuoteen ja on juuttunut kirjassaan sivulle 53 (P 57).

${ }^{3}$ Toki on huomattava, ettei romaanissa tehdä yksiselitteisesti selväksi, onko elämä, josta hän kertoo, hänen omansa vai jonkun toisen. Selvää kuitenkin on, että romaanissa estetään hänen pyrkimyksensä kertoa Martin Bormannin - nimensä romaanissa Robert Maseriksi vaihtaneen natsi-Saksan sotarikollisen - elämäntarina uudesta, ambivalentista näkökulmasta.

${ }^{4}$ Esim. Battersby (2006), Strawson (2004), Tammi (2009).

${ }^{5}$ Esim. Nilsson, N.G. (2004).

\section{Lähteet}

auster, Paul i 989: Moon Palace. Harmondsworth: Penguin.

BATTERSBy, JAMES L. 2006: Narrativity, Self, and Self-Representation. Narrative 14(1), $27-44$.

CRISP, PETER 2008: Between Extended Metaphor and Allegory: Is Blending Enough? Language \& Literature 17(4). 291-308.

FAUCONnier, GILles \& TURner, MARK 2002: The Way We Think. Conceptual Blending and the Mind's Hidden Complexities. New York: Basic Books.

KASTEN, MADELEIne 2005: Allegory. Teoksessa Routledge Encyclopedia of Narrative Theory. Ed. by David Herman et al. New York: Routledge.

LAKOFF, GEORGE \& JOHNSON, MARK I980: Metaphors We Live By. Chicago: Chicago UP. LINDGREN, TORGNY I 995: Hummelhonung. Stockholm: Norstedts.

LINDGREN, TORgNY I 999: I Brokiga Blads vatten. Stockholm: Norstedts. 
LINDGren, TORGNY 2002: Pölsan. Stockholm: Norstedts.

Lindgren, TORGNY 2005: Dorés bibel. Stockholm: Norstedts.

meretoja, hanna 2010: The French Narrative Turn. From the Prolematization of Narrative Subjectivity in Alain Robbe-Grillet's Dans le labyrinthe to its Hermeneutic Rehabilitation in Michel Tournier's Le Roi des Aulnes. Turku: Turun yliopisto.

NEUMANN, BIRGIT \& NÜNNING, ANSGAR 2008: Ways of Self-making in (Fictional) Narrative: Interdisciplinary Perspectives on Narrative and Identity. Teoksessa Narrative and Identity: Theoretical Approaches and Critical Analyses. Ed. by Birgit Neumann, Ansgar Nünning \& Bo Pettersson. Trier: Wissenschaftlicher Verlag Trier. 3-22.

NILSSON, MAGNus 2004: Mångtydigheternas klarhet: Om ironier hos Torgny Lindgren från Skolbagateller till Hummelhonung. Växjö: Växjö UP.

NILSON, N.G. 2004: Mahlers pölsa och formlösheten som form, intervju med Torgny Lindgren av Nils Gunnar Nilsson. <http://www.panorstedt.se/templates/Norstedts/Page. aspx?id=40317> (12.1.2007)

PeTtersson, во 2008: I Narrate, Therefore I Am? On Narrative, Moral Identity and Modernity. - Teoksessa Narrative and Identity: Theoretical Approaches and Critical Analyses. Ed. by Birgit Neumann, Ansgar Nünning \& Bo Pettersson. Trier: Wissenschaftlicher Verlag Trier. 23-36.

petTersson, Bо 20 I IA: Kuvittele! Mielikuvituksesta kirjallisuuden tutkimuksessa ja opetuksessa. Avain 4/2011. 61-77.

Pettersson, во 2о i в: Literary Criticism Writes Back to Metaphor Theory: Exploring the Relation between Extended Metaphor and Narrative in Literature. Teoksessa Beyond Cognitive Metaphor Theory. Perspectives on Literary Metaphors. Ed. by Monika Fludernik. New York: Routledge.

PÄIVÄRINTA, ANNE 2OIO: Kognitiivinen metafora runoanalyysin selkärankana? Dylan Thomasin "After the Funeral" -runon ruumiilliset kielikuvat ja koherenttiuden haaste. Avain 4/2010. 5-23.

RICOeUr, PAUl I984: Time and Narrative 1. Chicago: Chicago UP. RICOeUr, PAUl 1985: Time and Narrative 2. Chicago: Chicago UP. RICOEUR, PAUl I988: Time and narrative 3. Chicago: Chicago UP.

RICOeUr, PAUl 1991: Life: A Story in Search of a Narrator. Teoksessa A Ricoeur Reader: Reflection and Imagination. Ed. by Mario Valdés. New York: Harvester Wheatsheaf. 425-437.

RICOeur, Paul i 992: Oneself as Another. Chicago: Chicago UP.

Ricoeur, PAUl 2000: Tulkinnan teoria. Diskurssi ja merkityksen lisä. Helsinki: Tutkijaliitto.

RICOEUR, PAUl 2005: Mimesis, viittaus ja uudelleenhahmottuminen. Teoksessa Tulkinnasta toiseen: esseitä hermeneutiikasta. Toim. Jarkko Tontti. Tampere: Vastapaino. 
STRAWSON, GALEN 2004: Against narrativity. Ratio 17(4). 428-452.

TAMMI, PEKKA 2009: Kertomusta vastaan ("Ikävä tarina”). Teoksessa Näkökulmia kertomuksen tutkimukseen. Toim. Samuli Hägg, Markku Lehtimäki \& Liisa Steinby. 140-166.

TURUnen, Mikko 20i i: Semanttinen yhteisalue kielikuvien analyysin apuna. Avain 1/2011. 24-37.

TYRBerg, ANDERS 2002: Anrop och ansvar. Berättarkonst och etik hos Lars Ablin, Göran Tundström, Birgitta Trotzig, Torgny Lindgren. Stockholm: Carlsson.

werth, Paul i 999: Text Worlds: Representing Conceptual Space in Discourse. Harlow, Essex: Longman. 